\title{
Prospects for Russian Energy Exports in the Conditions of Implementing International Climate Policy Measures
}

\author{
V. V. Saenko ${ }^{a}$ and A. Yu. Kolpakov ${ }^{a, *}$ \\ a Institute of Economic Forecasting, Russian Academy of Sciences, Moscow, Russia \\ *e-mail: ankolp@gmail.com
}

Received April 19, 2021; revised May 11, 2021; accepted June 21, 2021

\begin{abstract}
The article examines two scenarios for the development of the world energy sector. According to the first, all countries are supposed to meet the objectives of the current energy and climate policy, and in it the world demand for hydrocarbons for 2018-2035 is growing by 10\%; according to the second scenario, it is additionally assumed that all countries will achieve Nationally Determined Contributions to the Paris Agreement, as a result of which the world consumption of hydrocarbons may decrease by $4 \%$. Arguments are given supporting Russia's ability to increase the export of hydrocarbons to foreign markets in both scenarios, at least in the next decade. In view of this, measures for intensifying the export of Russian hydrocarbons seem appropriate but the question arises about the rational use of generated income for the purpose of ensuring sustainable growth of the Russian economy and its regions.
\end{abstract}

Keywords: Paris Agreement, exports, oil, gas, coal, climate policy, carbon dioxide, energy consumption DOI: $10.1134 / \mathrm{S} 1075700721060137$

Today, the prospects for Russian energy exports are a highly debatable issue. On the one hand, modern scenarios for the development of the world energy sector developed by leading scientific and expert teams (e.g. [1-4]) are as follows: the peak of global coal and oil consumption either passed in 2019 or can be passed in the very near future. In general, in accordance with the forecasts, hydrocarbons will be replaced in the energy balance by low-carbon sources against the background of the efforts of the international community to mitigate climate change, the most important source of which is largely recognized as anthropogenic emissions of greenhouse gases, in particular, carbon dioxide $\left(\mathrm{CO}_{2}\right)$. On the other hand, production and infrastructure projects are being implemented in Russia aimed at increasing the export of hydrocarbons, in which significant investments are being made; the expansion of the Trans-Siberian and Baikal-Amur railways alone will cost almost a trillion rubles.

Such a contradiction brings about natural questions: will Russian export-oriented hydrocarbon projects be able to pay off or will their initiators (private and state structures) be forced to incur losses? How rational is the current intensified development of export flows in general, and will it not face a lack of demand?

In addition, the COVID-19 pandemic led to a decrease in world economic activity in 2020, which in turn caused a decrease in demand for oil, coal, and gas
[5-6], which is estimated at 9.6 and $4 \%^{1}$, respectively. Moreover, a significant drop in demand for hydrocarbons in 2020 was observed in the European and North American markets, where, for example, coal consumption decreased by $19-20 \%$ over the year. At the same time, the decline in energy demand in the Asian region was not so significant.

Certainly, it should be understood that "greening" scenarios for the global energy balance are drawn up with one clear goal: to demonstrate that technological solutions capable of reducing greenhouse gas emissions in order to mitigate climate change already exist; it is only necessary to develop appropriate policy measures and mechanisms to stimulate their large-scale implementation.

In this article, we have set another task: to assess what the potential demand for Russian energy resources may be, taking into account the climate goals and ambitions declared by different countries.

Scenarios of world demand for energy resources and export of hydrocarbons from Russia. In order to stimulate structural and technological modernization and combat climate warming, many countries have developed and implemented special policy measures

\footnotetext{
${ }^{1}$ These are preliminary estimates based on operational analytical materials from the US Energy Information Administration, International Energy Agency, Oil and Gas Journal. Accurate reporting data for 2020 were not available at the time of preparing this article.
} 


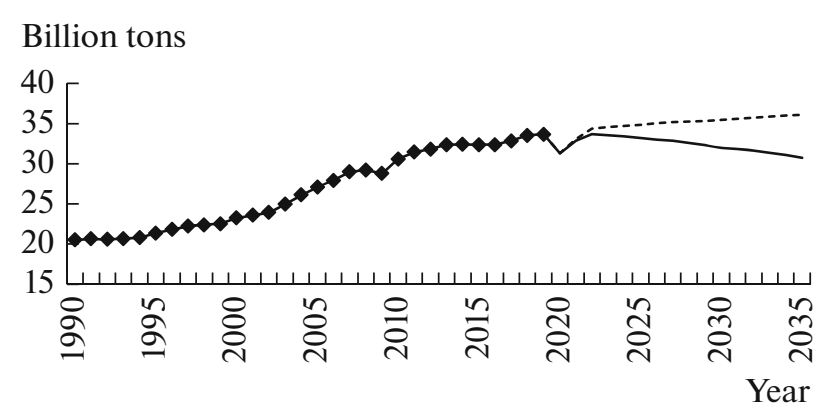

Fig. 1. World energy $\mathrm{CO} 2$ emissions in the considered scenarios: - - fact; - - CP scenario; - NDC scenario. Sources: IEA, BP (fact), IEF RAS (forecast).

(mainly in the energy sector) that set target values for development indicators for a certain year. They cover several key areas: energy efficiency and energy intensity of national economies or their individual sectors; structure and volumes of consumption of primary and final energy; power generation structure; the structure of the vehicles used; fuel efficiency; restrictions on greenhouse gas emissions in various sectors of the economy, and their carbon intensity.

In addition, under the Paris Agreement, most countries in the world have identified Nationally Determined Contributions (NDC). They are expressed either in setting an upper bound for the absolute level of greenhouse gas emissions (usually as a percentage of base year emissions) or in determining the required percentage reduction in the carbon intensity of the economy (specific greenhouse gas emissions per unit of GDP). The base year is most often 1990 or 2005; target reporting year is 2025,2030 , or 2035. Some countries (mainly developing African, Middle Eastern, Asian and Latin American) use their Business As Usual (BAU) scenario as a benchmark and set NDC targets relative to BAUs. It should also be noted that the target changes of the monitored indicators are sometimes set by a range of values. Here are some examples: Russia's NDC: emissions of all greenhouse gases (including the LULUCF sector-land use, land use change, and forestry) in 2030 should be $30 \%$ below the baseline emissions in 1990; China's NDC: specific $\mathrm{CO}_{2}$ emissions per unit of GDP in 2030 should be $60-65 \%$ lower than the 2005 baseline; Turkey's NDC: greenhouse gas emissions in 2030 should be $21 \%$ lower than those in the BAU scenario.

Based on the analysis of the targets set by all countries, two scenarios for the development of the world energy sector were developed, i.e.,

- CP (current policies) scenario, within the framework of which it is assumed that the tasks of all existing energy and climate policies will be fulfilled.

-NDC scenario in which, in addition to current policies, all countries reach their Nationally Deter- mined Contributions (NDC) under the Paris Agreement.

Scenario calculations were carried out on a system of models developed at the Institute of Economic Forecasting of the Russian Academy of Sciences for analyzing and forecasting the development of the world and Russian economy and energy, a component of which is a model, conventionally called " 42 ". ${ }^{2}$ It is a simulation model for estimating energy consumption and associated $\mathrm{CO}_{2}$ emissions in 50 countries and regions, which together represent the world. The model is used to calculate the effects of possible structural and technological changes as well as of energy efficiency improvement. The energy sector of all countries is detailed in the form of energy balances synchronized with the methodology of the International Energy Agency (IEA). The modeling is carried out "bottom-up": first, the final consumption of energy resources in the industrial, transport, residential, and service sectors is estimated; the required amount of primary energy resources is then calculated to meet the energy demand.

Figure 1 shows the dynamics of $\mathrm{CO}_{2}$ emissions due to the global energy consumption of hydrocarbons for the generated scenarios.

In the CP scenario, the measures adopted by the policies are insufficient to "reverse" the upward trend in the dynamics of energy $\mathrm{CO}_{2}$ emissions, as a result, they will increase from 33.5 billion tons in 2018 to 36.1 billion tons in 2035 . The NDC scenario is very different in this respect. If all countries fulfill their goals (NDC) declared under the Paris Agreement, $\mathrm{CO}_{2}$ emissions will be steadily decreasing at an average annual rate of $-0.6 \%$, as a result, by 2035 their volume will amount to 30.7 billion tons, which will correspond to the level of 2010.

Figure 2 shows the forecast of world primary energy consumption. It increases in both scenarios, despite a significant decrease in the energy intensity of global GDP by $32 \%$ by 2035 compared to 2018 in the CP scenario and by $37 \%$ in the NDC scenario. For the period 2018-2035 in the CP scenario, it will increase from 14.3 to 16.7 billion toe (by $17 \%$ at an average annual rate of $0.9 \%$ ); in the NDC scenario, up to 15.4 billion toe (by $8 \%$ at an average annual rate of $0.5 \%$ ).

The general trend is a decrease in demand for coal, which is primarily due to a shrinking use of thermal coal grades in the electricity and heat generation sector. Under compliance with the Paris Agreement, the process of transition of metallurgical production from converters to electric smelting is intensified, which also restrains the consumption of coking coal. The total consumption of coal, which amounted to 3.8 billion toe in 2018, is declining by 2035 to 3.5 billion toe

\footnotetext{
${ }^{2}$ A description of the model is given, for example, in: https://paris-reinforce.epu.ntua.gr/detailed_model_doc/42.
} 


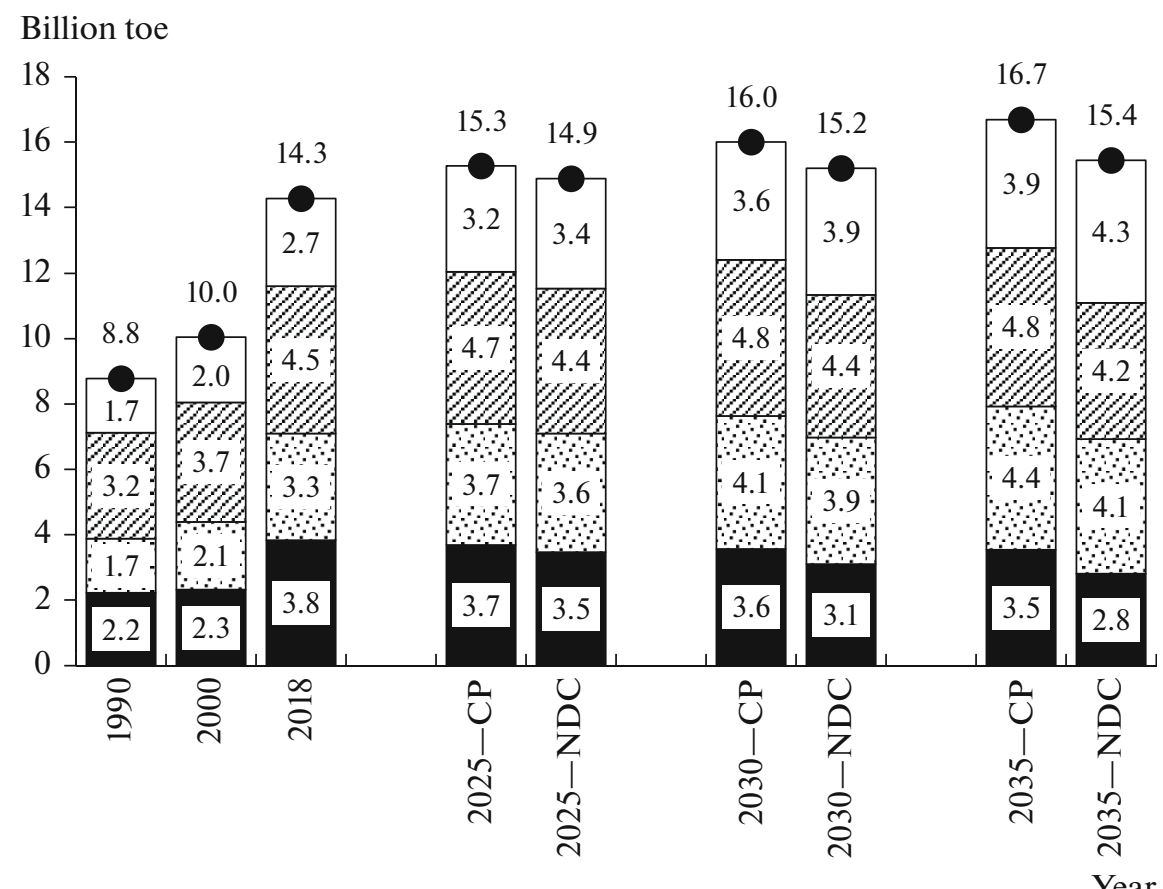

Fig. 2. Volume and structure of world primary energy consumption in the considered scenarios: $\square$ coal; $\therefore$ natural gas; $Q$ oil; carbon-free sources; $\bullet$ total. Sources: IEA (fact), IEF RAS (forecast).

in CP scenario and up to 2.8 billion toe in the NDC scenario.

Consumption of natural gas [7] and energy from carbon-free sources also grows in both scenarios. In the CP scenario, the increase in their consumption is approximately the same: by $1.1-1.2$ billion toe for the period up to 2035. In the NDC scenario, demand for carbon-free energy is growing at an accelerated rate of 1.6 billion toe by 2035 while natural gas consumption is increasing by 0.8 billion toe The key factors behind this dynamics are the replacement of existing coal generation as well as the gradual phasing out of new coal projects in the electric power sector, which are inferior to projects based on gas and carbon-free sources.

The prospects for oil consumption fundamentally depend on the scenario, according to which the world energy sector will develop. If the countries' obligations under the Paris Agreement remain largely unfulfilled, global oil demand will continue to increase until 2035 although the average annual growth rate will be low: $0.5 \%$ in the period until 2030 and $0.1 \%$ in $2030-2035$.

According to the NDC scenario, the peak of world oil consumption will be passed in the coming years, in the period up to 2030 there will be a stabilization at 4.4 billion toe, and by 2035, consumption will decrease to 4.2 billion toe. The main factors of a potential slowdown in oil demand are the development of electric transport, an increase in the fuel efficiency of transport, a shift from oil products to electricity in the residential and service sectors, and a change in the structure of bunkering fuel in favor of nonoil sources.

As a result, according to the scenarios, the share of coal in the structure of world energy consumption for 2018-2035 will decrease from 27 to $18-21 \%$; the share of natural gas will increase from 23 to $26-27 \%$; the share of carbon-free sources will rise from 19 to $23-$ $28 \%$; and the share of oil will be reduced from 31 to 27-29\% (larger structural shifts are expected according to the NDC scenario).

In the regional context, the situation with energy consumption is twofold. On the one hand, in North America and Europe, the total primary energy consumption in 2018-2035 will decrease from 4.6 to 4.4 billion toe according to the CP scenario and up to 4 billion toe according to the NDC scenario. On the other hand, in Asia and other regions, which include developing countries (Central and South America, the Middle East, and Africa), energy consumption will continue to increase regardless of the scenario. It is with Asia that the main prospects for growth in demand for hydrocarbons are associated [8-9]. While at present Asian economies provide $74 \%$ of world consumption of coal, $36 \%$ of oil, and $21 \%$ of gas, by 2035 these indicators will significantly increase: up to $82-$ $83 \%, 42-43 \%$, and $32-36 \%$, respectively, depending on the scenario.

Thus, the implementation of the CP scenario leads to a gradual increase in global consumption of hydrocarbons from 11.6 billion toe in 2018 to 12.8 billion toe 
in 2035. Undoubtedly, the volumes of coal consumption are decreasing, but the growth in demand for oil and natural gas compensates for the decline in the coal segment. In addition, it should be borne in mind that the drop in coal consumption will be accompanied by a simultaneous decrease in its production in Europe and China, therefore, the pressure on the volume of world trade will be less.

The main effects of the NDC scenario implementation consist in the reduction in the volume of potential demand for hydrocarbons in the world to 11.1 billion toe by 2035 as well as in the drop in their potential sale prices [10]. For the primary energy sector of Russia, the response to these risks should be increased competitiveness in the context of low prices on energy markets. For the natural gas market, the risks are lower, as demand grows in the NDC scenario as well. However, due to restrictions, the export of oil and coal cargoes from Russia may reach peak values by 2030 .

At the same time, we are confident that the high competitiveness of Russian hydrocarbons in the world markets will mitigate the risks of declining demand in the NDC scenario. First, in Russia there is a wellknown mechanism for adapting the energy sector to the deterioration in the situation on the world markets, namely, the devaluation of the national currency, which allows reducing the "dollar" costs of the production and transportation of hydrocarbons, thereby adjusting the economy of the export supply chains to the prevailing conditions. Second, the country has built and is developing a reliable system of export supplies, including an extensive pipeline, railway, and port-transshipment systems. Third, an important condition for maintaining the profitability of Russian hydrocarbons is low production costs as well as a flexible tax policy of the state in the field of subsoil use.

In practice, this means that in the face of tougher price competition in the world energy markets, the share of Russian hydrocarbons (in percentage terms) is likely to be higher than in scenarios of a favorable mar- ket environment. At the same time, the narrowing of the hydrocarbon market in the NDC scenario is still decisive and leads to the potential export volumes of Russian hydrocarbons turning out to be lower than in the CP scenario if all countries comply with the conditions of the Paris Agreement.

The Table 1 shows estimates of the export of hydrocarbons from Russia in the considered scenarios.

In 2019-2035, the export of oil and oil products may increase from 412 to 425-470 million tons; natural gas exports from 260 to $350-439$ billion cubic meters; coal exports from 205 to 261-319 million tons (lower values correspond to the NDC scenario). At the same time, the export of oil and coal may reach peak values in 2030 in the NDC scenario, after which it will begin to decline. The CP scenario, as well as the export of natural gas in both scenarios, are characterized by growing dynamics up to 2035.

The indicated values of the natural gas and coal exports generally correspond to the ranges laid down in the Energy Strategy of the Russian Federation for the period up to 2035 (hereinafter ES-2035) although they are closer to their lower values. This could indicate that ES-2035 underestimates the risks associated with the pursuing the climate agenda and the implementation of the Paris Agreement. At the same time, the range of oil exports in ES-2035 is below our estimates. This is due to the systematic underestimation of the potential and competitiveness of the Russian oil sector on the part of federal agencies and ES developers: the official forecasts of oil production in Russia are traditionally below the levels that the industry reaches within the framework of production activities. Thus, in the Energy Strategy for the period up to 2020, according to the most optimistic scenario, it was assumed that oil production volumes would be at the level of 520 million tons; in the Energy Strategy for the period up to 2030, 535 million tons; in the General scheme for the development of the oil industry for the period up to 2020, 511 million tons. In fact, in 2019, oil

Table 1. Scenarios for the export of hydrocarbons from Russia

\begin{tabular}{l|c|c|c|c|c|c|c}
\hline \multicolumn{1}{c|}{ Indicator } & 2000 & 2010 & 2019 & 2025 & 2030 & 2035 & $2035($ ES-2035) \\
\hline $\begin{array}{l}\text { Oil and oil products, million tons } \\
\quad \text { CP scenario }\end{array}$ & 207 & 380 & 412 & 443 & 458 & 470 & $371-408$ \\
$\quad$ NDC scenario & & & & 426 & 431 & 425 & \\
Natural gas, billion cubic meters & 194 & 191 & 260 & 326 & 386 & 439 & $363-490$ \\
$\quad$ CP scenario & & & & 297 & 324 & 350 & \\
$\quad$ NDC scenario & 44 & 117 & 205 & 258 & 293 & 319 & $257-392$ \\
Coal, million tons & & & & 249 & 264 & 261 & \\
$\quad$ CP scenario & & & & & \\
$\quad$ NDC scenario
\end{tabular}

Sources: Rosstat, Federal Customs Service of Russia (fact), Institute of Economic Forecasting, Russian Academy of Sciences (forecast), ES-2035. 
production in Russia exceeded 560 million tons. This is probably why the upper scenario in ES-2035, which was approved in mid-2020, still allows for oil production of 560 million tons in 2024 although in the longer term it still retains a restrained attitude: by 2035 , the maximum expected production volume is 555 million tons.

Arguments for the feasibility of prospective increase in exports of oil and coal from Russia. There are two aspects that require separate argumentation based on the results of constructing scenarios for global energy consumption and hydrocarbon exports from Russia.

The first concerns our optimistic view on the ability of the Russian oil sector to increase supplies to the external market, which is at odds with the position of ES-2035. There are two important arguments here.

1. Figure 3 shows a comparison of the economics of oil supplies from the main producing countries at a relatively low Brent price of $50 \mathrm{USD} / \mathrm{bbl}$. It can be seen that Russian oil production remains profitable even with a not-very-favorable price environment and taking into account its capital intensity. It cannot be called the most economically competitive, since in terms of income it is inferior to a number of OPEC countries in the Middle East. However, if we compare it with offshore production in Africa or Brazil, the Russian performance remains more attractive. This suggests that it is possible to maintain a significant market niche even with a shrinking market. The economic competitiveness of Russia in a low price environment may prove to be an important advantage, especially in the event of starting "price wars" in shrinking energy markets (against the backdrop of the withdrawal from the OPEC + deal).

2. Oil production in Russia can continue to grow even in the face of low prices on the world market. Important factors that ensure the profitability of Russian reserves are 1) moderate production costs, which in dollar terms decreased after the devaluation of the ruble in 2014 (in 2016, which was the most difficult year for the industry, the average production costs, taking into account depreciation deductions, amounted to $10 \mathrm{USD} / \mathrm{bbl}$ and the total cost price including the tax on the extraction of minerals amounted to $22 \mathrm{USD} / \mathrm{bbl}$ ); 2) flexible tax policy of the state, which provides a wide range of benefits for different categories of oil deposits. Largely due to the balanced approach of the Russian Government to taxation, the industry systematically exceeded production expectations laid down in state strategic documents.

The second aspect is related to the controversial nature of our assumptions about export supplies of coal from Russia against the background of the expected stagnation or even a decrease in total global demand.

Coal export from Russia has some features that must be taken into account when forecasting it. The first is the unfavorable geographical position of the

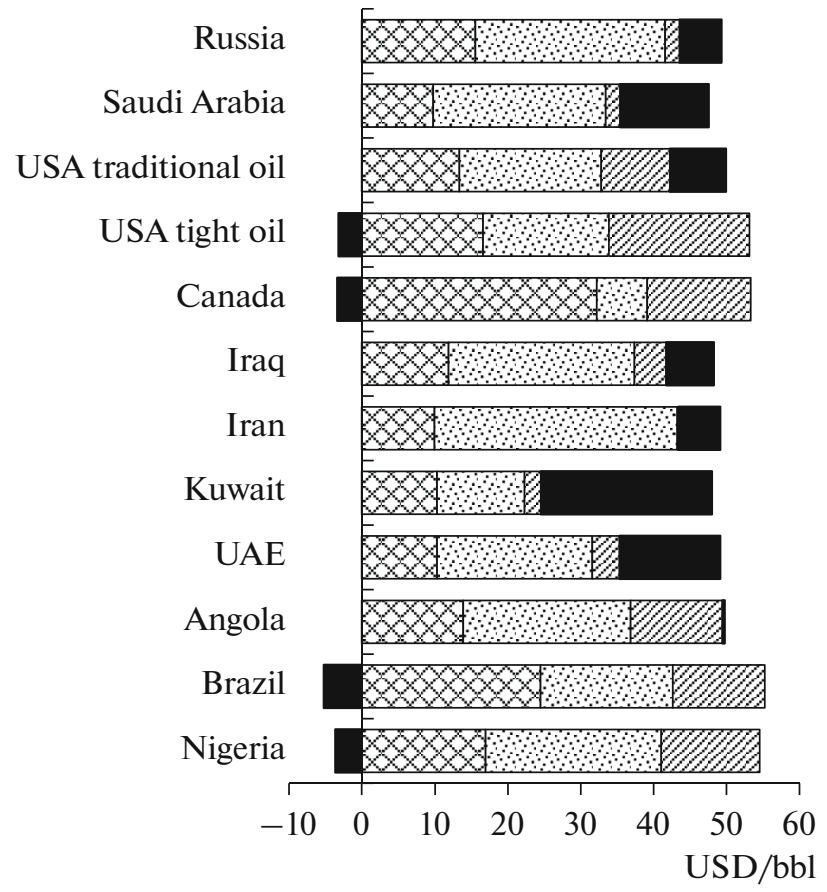

Fig. 3. Comparison of the economics of oil supplies from the main producing countries at a Brent price of $50 \mathrm{USD} / \mathrm{bbl}$ :

7 production and transportation costs; 9 tax payments; $\square$ capital expenditures from profit; $\square$ revenues.

Source: IEF RAS estimates.

main export supply centers in relation to the coal sales markets. For example, the Kuznetsk coal basin (the largest region [11], which accounts for about $70 \%$ of coal exports) is located at a distance of about four thousand kilometers from the western ports and more than five thousand kilometers from the eastern ports of the country. As a result, the share of transport costs for the delivery of coal in the export price in Russia is one of the highest in the world. ${ }^{3}$ The second feature is associated with the pronounced cyclicality of coal prices in the world market. As a result, the industry

\footnotetext{
${ }^{3}$ Analysis of the FOB price structure of the main coal exporters allows us to distinguish three groups of countries. The first group includes countries with a low specific weight of logistics costs (transport to the port and transshipment in the port). These include Colombia and Indonesia (share of logistics costs $10-15 \%)$. At the same time, the main part of FOB costs for these countries is associated with the extraction and processing of coal (about 70\%). The second group consists of countries with average values of logistics costs $(20-30 \%)$ and relatively high costs of mining and processing of coal (South Africa and Australia). And finally, the third group, which includes Russia and the United States, is characterized by high logistics costs (45-55\%) and average costs of coal mining and processing. Moreover, Russia is characterized by an extremely high value of the cost of coal transshipment (up to $20 \%$ with an average value in the world of about $6 \%$, which, in particular, is a consequence of the lack of transshipment capacities, especially in the eastern ports of the country) and a very low share of taxes (about $3 \%$ ).
} 
periodically experiences difficult (for example, 20122015, when the free cash flow was negative) and "successful" periods (for example, in 2017-2018 net cash flow annually exceeded investments by an average of 140 billion rubles). ${ }^{4}$

Taking into account the noted features, nevertheless, a number of convincing arguments can be put forward in favor of scenarios for an increase in Russian coal exports.

1. In the eastern direction, the demand for Russian coal significantly exceeds the export capacity of the Russian infrastructure. According to the available data presented at several meetings on the operational and strategic development of the industry, in 2019-2020, at least 40 million tons of coal failed to be exported from Kuzbass in the direction of the eastern ports due to logistics constraints, although consumers were ready to accept these volumes despite the climate agenda. Taking into account the effective market prices, the lost revenue of the Russian business can be estimated at about 2.5 billion US dollars over those two years.

2. The country has launched a large-scale project of the Transsib and BAM expansion in compliance with the instructions of the President of the Russian Federation following the meeting of the Commission on the development strategy of the fuel and energy complex and environmental security of August 27, 2018, according to which a target was determined: a doubling of Russian coal supplies to the east up to 200 million tons by 2025 [12]. In addition, it is planned to synchronize the railways expansion with the development of coal terminals on the Pacific coast of Russia. The implementation of these projects allows us to expect the resolution of many accumulated infrastructure problems and will increase the export of coal to Asia.

3. In Asian countries, new coal-fired generating capacities are being actively put into operation but their structure is dominated by highly efficient modern technologies that use high-quality high-calorific coals. Russia is one of the countries that are able to meet the demand for such coals. The Russian coal business takes into account these features of current and future demand and actively uses them. In particular, the country is constantly making efforts to increase the volume of coal beneficiation, which not only better meets expectations on the demand side, but also contributes to an increase in the actual sale prices [13].

4. With regard to Indonesia, which is a major supplier of coal to foreign markets, there was a consensus forecast, according to which the rapidly growing national economy will divert an increasingly significant share of coal production to itself, which will limit

\footnotetext{
${ }^{4}$ At the same time, during periods of high prices, the average share of transportation costs in the FOB coal price decreases to $30 \%$ and in years of low prices, it increases to $40 \%$.
}

the country's export opportunities up to the expected decrease in coal export volumes [13].

5. In addition to the devaluation of the ruble (as discussed above), there is another factor that contributes to the profitability of Russian coal export chains, even during difficult periods. We mean subsidizing ${ }^{5}$ rail transportation of coal. The Russian government has repeatedly demonstrated its readiness to apply this measure in order to support the industry.

6. Most studies [15-17] on the prospective development of the coal industry predict a shift in production to the eastern regions, primarily to the Far Eastern Federal District. Thus, in the considered scenarios, which are presented in this study, the share of the Far Eastern Federal District in the total coal production increases from the current $17 \%$ to $22-28 \%$. This territorial shift is due to the fact that the entire increase in demand for Russian coal is expected in Asian countries. The expected perspective location of coal mining will significantly lessen the load on the country's railway infrastructure and will also help to reduce the transport shoulder, i.e., it will have a positive effect on the competitiveness of Russian coal in Asia.

7. Coal demand is expected to gradually shift from the northeastern (Japan, South Korea, China) to the southwestern (Malaysia, Vietnam, Bangladesh, Philippines, Pakistan, Thailand, and especially India) part of Asia. At the same time, Russia has the opportunity to provide economically comparable supplies to India along the western route via the Black Sea and Baltic ports (due to the shorter railway distance to them in comparison with the eastern ports). This approach will also make it possible to ensure loading western railway capacity, which will be freed up due to the fall in demand for coal in Europe.

The aforementioned arguments substantiate the positive vision of Russia's ability to increase coal supplies to foreign markets. However, at the same time, the question of the rational use of income generated by the coal sector remains open.

Figure 4 shows the estimated distribution of the coal sector rent among the beneficiaries. The problem

\footnotetext{
${ }^{5}$ It should be understood that subsidizing railroad transportation of coal for export, on the one hand, significantly increases its competitiveness in world markets, but on the other hand, diverts significant resources from the state budget or the budget of a state-owned company. Estimates of the effectiveness of energy subsidies for the country's economy presented in the framework of various macroeconomic studies, are controversial. However, as noted in [14], the acceleration of economic development due to energy subsidies is limited to a certain threshold value, after which the factor of lower efficiency is more likely to prevail. A possible way to solve this problem is the damping mechanism currently under consideration, which will link the size of the railway tariff for coal exports with world prices. Given that during the period of low prices, a discount will be provided to the export tariff, and during the period of high prices, a premium will be applied. A similar mechanism can be used to regulate the tariff for coal transshipment in Russian ports. This will ensure greater stability in Russian coal exports.
} 


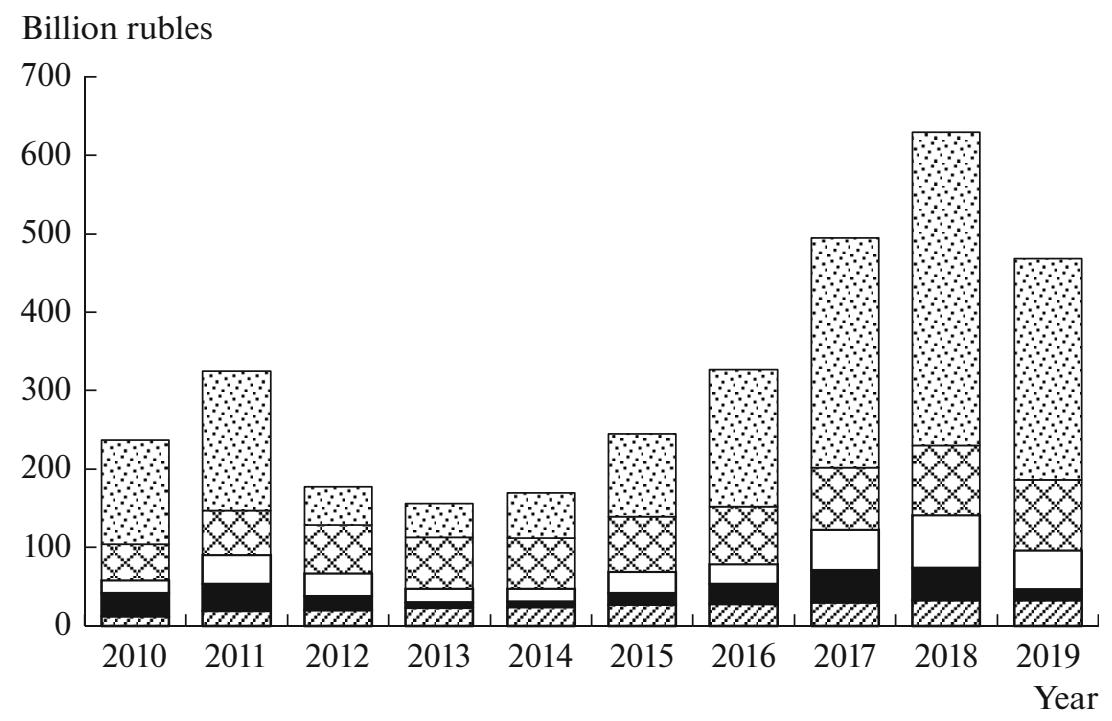

Fig. 4. Assessment of the distribution of rent in the coal sector:

$Q$ insurance deductions to the Pension Fund, contributions to Social Insurance Fund, Federal Statutory Health Insurance Fund; $\square$ federal budget, $\square$ regional and local budgets; $\square$ wages and salaries; $\because$ net profit and depreciation of the coal sector. Sources: Rosstat, Federal Tax Service of Russia, Institute of Economic Forecasting (Russian Academy of Sciences).

is that regional and local budgets receive only about $10-11 \%$ of total revenues.

The maximum nominal values were reached in 2018 and are estimated at 67 billion rubles, and on average for 2015-2019 this value was 44 billion rubles a year. In addition, another 70-90 billion rubles (actual values for 2015-2019) remains in the regions in the form of wages. Unfortunately, in such conditions it is simply impossible to ensure the sustainable development of the coal-mining regions [18]. We imply here not only a decent level of income but also the environment and the quality of life for the population.

The situation is complicated by the fact that the economy of the coal industry is cyclical [19]. If the state decides to introduce the redistribution of coal rent, its effective tool should have the following characteristics:

- To be applied to the revenues of the coal sector but only during periods of high profitability, i.e., to be flexible in relation to the economic performance of the industry.

- Income should be redistributed in favor of the regions rather than the federal budget. In the "successful" years of favorable pricing conditions in the energy markets, the federal budget of Russia is already in surplus.

Conclusions. The climate agenda and the task undertaken by the world economy to enter a development trajectory characterized by low greenhouse gas emissions has an increasing impact on the prospects for the performance of the world energy sector [20]. If the goals stated in the framework of the Paris Agree- ment are achieved, the total global consumption of hydrocarbons for 2018-2035 could decrease by 5\%. However, the current policy measures are not yet sufficient to implement such a scenario; without intensifying climate efforts, the demand for hydrocarbons will exceed the current values by $10 \%$.

Russian hydrocarbons have a high economic competitiveness in foreign markets, as a result, in the next decade, an increase in their export supplies can be expected. In the scenario of ambitious structural shifts in favor of low-carbon solutions, the peak of oil and coal exports from Russia can be reached by 2030, then they will begin to decline slowly. This means that Russia has a window of opportunity, and in this connection, measures to intensify the export of hydrocarbons look appropriate.

It is necessary to diversify the geographic structure of hydrocarbon exports from Russia towards Asian and other developing economies. It is in these regions that the main increase in demand for hydrocarbons is expected. At the same time, the share of Asia in the total export of Russian energy resources may grow from $27 \%$ in 2018 to $45-50 \%$ in 2035 , including the respective rise in coal exports from 50 to $65-70 \%$.

It is advisable to maintain in the medium term the subsidies for railroad transportation of coal for export, which can later be replaced by a damping mechanism linking the size of the tariff for transportation and transshipment of coal with world prices for solid fuel. The preservation of favorable conditions for railway transportation should be assessed not only from the viewpoint of their economic efficiency but also taking 
into account the multiplier effects they create for regional economic complexes.

It is necessary to strive for the most efficient use of resource rent. The potential limitation of demand for domestic hydrocarbons in ten years means that Russia has perhaps the last chance to use energy revenues for the structural and technological modernization of the national economy. Unless a qualitative leap forward in the development of the nonenergy sector is achieved in the medium term, the Russian economy will not be able to make up for the loss of hydrocarbon export revenues that could arise from international efforts aimed at transition to a low-carbon economy.

In the coal industry, it is advisable to ensure the redistribution of rent in favor of regional budgets. This may help to significantly improve the socioeconomic situation of depressed regions, primarily in the east of the country, and reduce the environmental stress in coal-mining regions.

\section{FUNDING}

This research was funded by the Ministry of Science and Higher Education of the Russian Federation within the framework of grant for large scientific projects in priority directions of scientific and technological development no. 075-15-2020-804/13.1902.21.0016 dated 02.10.2020 entitled "Socio-economic development of Asian Russia based on the synergy of transport accessibility, system knowledge about natural resource potential, expanding space of interregional interactions".

\section{REFERENCES}

1. DNV GL, Energy Transition Outlook 2020. https://download.dnvgl.com/eto-2020-download.

2. BP, Energy Outlook 2020. https://www.bp.com/en/global/corporate/energy-economics/energy-outlook.html.

3. IRENA. World Energy Transitions Outlook: $1.5^{\circ} \mathrm{C}$ Pathway. 2021. https://www.irena.org/publications/ 2021/March/World-Energy-Transitions-Outlook.

4. McKinsey \& Company, Global Energy Perspective 2021. https://www.mckinsey.com/industries/oil-andgas/our-insights/global-energy-perspective-2021.

5. A. M. Mastepanov, "Big cycles and black swans," Energ. Polit., No. 6, 4-19 (2020).

6. A. I. Gromov, "Is a "blue" transformation of the energy transition possible in the "post-covid" future of European power economy?" Energ. Polit., No. 7, 58-69 (2020).

7. J. Stern, "The role of gases in the European energy transition," Russ. J. Econ. 6, 390-405 (2020).

https://doi.org/10.32609/j.ruje.6.55105
8. V. V. Klimenko, A. V. Klimenko, A. G. Tereshin, and T. A. Mitrova, "Impact of climate changes on the regional energy balances and energy exports from Russia,” Therm. Eng. 66, 3-15, (2019).

https://doi.org/10.1134/S004060151901004X

9. Global and Russian Energy Outlook 2019, Ed. by A. A. Makarov, T. A. Mitrova, and V. A. Kulagin (Energy Research Institute, Russian Academy of Sciences, Moscow School of Management SKOLKOVO, Moscow, 2019). https://www.eriras.ru/files/forecast_2019_en.pdf .

10. A. A. Makarov, T. A. Mitrova, and V. A. Kulagin, "Long-term development of the global energy sector under the influence of energy policies and technological progress,” Russ. J. Econ. 6, 347-357 (2020). https://doi.org/10.32609/j.ruje.6.55196

11. I. G. Tarazanov and D. A. Gubanov, "Results of the work of the coal industry in Russia for January-December 2020," Ugol', No. 3, 27-43 (2021).

https://doi.org/10.18796/0041-5790-2021-3-27-43

12. V. Golovshchikov, D. Ognev, and E. Petryakova, "Prospects of the Baikal-Amur Mainline and the Trans-Siberian railway taking into account the state of the regions and the development of the coal industry," Energ. Polit., No. 2, 30-43 (2021).

13. Y. Malyshev, A. Kovalchuk, and A. Rozhkov, "Coal industry: Search for landmarks in an era of change," Energ. Polit., No. 2, 18-29 (2021).

14. V. Polterovich, V. Popov, and A. Tonis, "Mechanism of the resource curse and economic policy," Vopr. Ekon., No. 6, 4-27 (2007). https://doi.org/10.32609/0042-8736-2007-6-4-27

15. A. B. Yanovskiy, "Results of structural restructuring and technological re-equipment of the coal industry in Russia and tasks for long-term development," Ugol', No. 8, 8-16 (2019).

https://doi.org/10.18796/0041-5790-2019-8-8-16

16. V. V. Saenko, "Coal industry of Russia: challenges and modern development trends," Okruzh. Sreda Energoved., No. 3, 70-96 (2019).

17. L. S. Plakitkina and Yu. A. Plakitkin, Coal Industry of the World and Russia: Analysis, Trends and Development Prospects (Litterra, Moscow, 2017) [in Russian].

18. "Will the access to the subsoil be restricted?" Ugol' Kuzbassa, No. 1, 8-10 (2018). http://www.uk42.ru/index.php?id=6903.

19. L. V. Kusurgasheva, A. K. Muromtseva, A. A. Bakanov, and E. V. Prokopenko, "Cyclic factors and systemic constraints on the development of the coal industry in Russia," Ugol', No. 10, 33-38 (2020).

https://doi.org/10.18796/0041-5790-2020-10-33-39

20. L. M. Grigoryev and D. D. Medzhidova, "Global energy trilemma,” Russ. J. Econ. 6, 437-462 (2020). https://doi.org/10.32609/j.ruje.6.58683

Translated by I. Pertsovskaya 